\title{
The Green Eating Project: web-based intervention to promote environmentally conscious eating behaviours in US university students
}

\author{
Jessica T Monroe ${ }^{1}$, Ingrid E Lofgren ${ }^{1}$, Becky L Sartini ${ }^{2}$ and Geoffrey W Greene ${ }^{1, *}$ \\ 'Department of Nutrition and Food Sciences, University of Rhode Island, 10 Ranger Road, Ranger Hall, Kingston, \\ RI 02881, USA: ${ }^{2}$ Department of Fisheries, Animal and Veterinary Sciences, University of Rhode Island, Center for \\ Biotechnology \& Life Sciences, Kingston, RI, USA
}

Submitted 29 June 2015: Accepted 3 July 2015: First published online 18 August 2015

\begin{abstract}
Objective: To investigate the effectiveness of an online, interactive intervention, referred to as the Green Eating (GE) Project, to motivate university students to adopt GE behaviours.

Design: The study was quasi-experimental and integrated into courses for credit/ extra credit. Courses were randomly stratified into experimental or non-treatment control. The 5-week intervention consisted of four modules based on different GE topics. Participants completed the GE survey at baseline (experimental, $n$ 241; control, $n$ 367) and post (experimental, $n$ 187; control, $n$ 304). The GE survey has been previously validated and consists of Transtheoretical Model constructs including stage of change (SOC), decisional balance (DB: Pros and Cons) and selfefficacy (SE: School and Home) as well as behaviours for GE. Modules contained basic information regarding each topic and knowledge items to assess content learning.

Setting: The GE Project took place at a public university in the north-eastern USA. Subjects: Participants were full-time students between the ages of 18 and 24 years. Results: The GE Project was effective in significantly increasing GE behaviours, DB Pros, SE School and knowledge in experimental compared with control, but did not reduce DB Cons or increase SE Home. Experimental participants were also more likely to be in later SOC for GE at post testing.

Conclusions: The GE Project was effective in increasing GE behaviours in university students. Motivating consumers towards adopting GE could assist in potentially mitigating negative consequences of the food system on the environment. Future research could tailor the intervention to participant SOC to further increase the effects or design the modules for other participants.
\end{abstract}

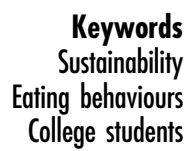

Keywords

ating behaviours College students
With the world population projected to increase to 9 billion by the year $2050^{(1)}$, the challenges and complexities of feeding this population sustainably have come to the forefront. Sustainability is the ability to meet current needs of food production without compromising the ability of future generations to meet their needs and is critical to every aspect of the food system including production, processing, distribution, consumption and disposal of food ${ }^{(2)}$. A sustainable food system should not excessively use environmental or economic resources and should also produce social benefits such as supporting the local community. Aspects of the current food system can be considered unsustainable due to the excessive reliance on natural resources, loss of land and biodiversity, as well as air and water pollution ${ }^{(1,3-6)}$.
Consumers have the opportunity to play a critical role in moving the food system towards sustainability through their dietary choices by adopting environmentally and socially conscious eating behaviours, also known as Green Eating $(\mathrm{GE})^{(7)}$. GE has been defined for consumers as follows: eating locally grown foods, limiting amounts of processed/fast foods, eating meatless meals at least one day per week, choosing organic foods as much as possible, and only taking what you plan on eating ${ }^{(7,8)}$.

Although there are conflicting studies ${ }^{(9-11)}$, most research has found transportation of local or domestically produced foods to emit fewer greenhouse gases compared with imported foods ${ }^{(12-17)}$, particularly foods imported by air ${ }^{(17)}$. Purchasing local foods can also have a 
positive impact on the local economy by returning more money to local farmers instead of distributors or manufacturers ${ }^{(18-20)}$. With regard to protein choice, animal protein sources generally utilize more resources and increase pollution more than plant protein sources ${ }^{(5,21-23)}$. Certain animal production methods and certain animal varieties, such as beef, have been implicated as emitting more greenhouse gases ${ }^{(16,22)}$ and utilizing more natural resources such as fossil fuel and water ${ }^{(24,25)}$ than other proteins. Shifting diets towards animal and plant protein sources that produce the least amount of greenhouse gases and utilize less resources has been cited as a more environmentally conscious food choice ${ }^{(5,21,23)}$. Reducing food waste, another aspect of GE, could potentially reduce the excessive consumption of natural resources ${ }^{(26)}$. The amount of food waste in the USA is about $40 \%{ }^{(27)}$ and has been calculated to equal 300 million barrels of oil and one-quarter of freshwater use annually ${ }^{(26)}$. An additional 4 million Americans could be fed every day by diverting $5 \%$ of food waste from landfills ${ }^{(28)}$. In addition to the topics reviewed above, students considered choosing organic foods and reducing processed/fast foods as meaningful parts of the $\mathrm{GE}$ construct ${ }^{(7)}$ but these topics were not included in the GE Project intervention due to resource limitations and, therefore, the environmental effect of these topics is beyond the scope of the current paper.

Informing consumers of more sustainable food choices and eating habits within the food system could lead to behaviour changes. University students are a unique target population because, at this stage in their life, they are forming their identity and solidifying the foundation of their beliefs and attitudes ${ }^{(29)}$. Studies have investigated university students' perspectives and knowledge about topics similar to GE such as sustainable agriculture ${ }^{(30)}$, local/seasonal foods ${ }^{(31)}$, organic foods ${ }^{(32)}$, food waste ${ }^{(33)}$ or a combination of these types of topic ${ }^{(34,35)}$. Other studies have investigated the association between attitudes towards these topics and dietary quality in university students $^{(35,36)}$. Few interventions exist addressing these topics within the university population, and take place either in the dining hall ${ }^{(33)}$ or in a classroom setting ${ }^{(37)}$. Online interventions focusing on other targets conducted in this population were successful in motivating dietary behaviour changes ${ }^{(38-41)}$. To the knowledge of the researchers, no online intervention exists motivating university students to adopt GE behaviours. Therefore, the objective of the GE Project was to investigate if an online intervention focused around sustainable aspects of GE (local eating, reducing waste and choosing environmentally friendly proteins) could increase GE behaviours in university students. It is hypothesized that the experimental group exposed to the intervention will significantly increase GE behaviours compared with a non-treatment control group.

\section{Materials and methods}

\section{Study design}

The GE Project was integrated into four general education courses including writing, animal sciences, nutrition sciences and an introduction to the university course for credit or extra credit. A variety of academic disciplines enrol in general education courses. The GE Project utilized a quasi-experimental design; courses were randomized and those with multiple sections (the same course taught at different times) were randomized by section into the experimental or control groups. Course announcements were made and professors provided student contact information to researchers. Students ( $n$ 1248) were sent a link to the GE Project. They were provided instructions on how to register by creating a username and password. The GE Project was 5 weeks in duration with students completing baseline and post assessments at week 1 and week 5 , respectively. The experimental group received the intervention consisting of one of four modules per week. The control group did not receive the intervention but completed an unrelated online survey as well as the pre and post assessments for class credit. Participants in the GE Project had to be students between the ages of 18 and 24 years and provide online consent for their data to be used for research. Participants were excluded if they were outside the age range or did not provide consent. The Institutional Review Board of the University of Rhode Island approved the study.

\section{Intervention}

The experimental intervention contained four modules related to GE constructs: (i) Introduction to GE; (ii) Eat Local; (iii) Reduce Waste; and (iv) Environmentally-friendly Protein (see Table 1). Each module began with an introductory quiz about the participant's habits corresponding to the module topic followed by feedback as a way to engage the participant. Content for the module consisted of basic information displayed as text, pictures, video clips and through interactive questions and answers. Each module had two specific learning objectives associated with the topic. Following the content, participants completed an assessment quiz to demonstrate their learning. Finally, participants were asked to choose a behavioural goal to follow through on the learning objectives.

\section{Measurements}

\section{Green Eating survey}

The GE survey was completed to assess primary outcomes, demographic and behavioural variables. The survey was developed in 2011 to assess participants' readiness to adopt GE behaviours. The survey measures various aspects of GE that correspond to the Transtheoretical Model such as stage of change (SOC), 
Table 1 Green Eating (GE) Project module content

\begin{tabular}{lll}
\hline Title & Educational objectives & Behavioural objectives \\
\hline Green eating intro $^{(25,53,56)}$ & $\begin{array}{l}\text { - What constitutes the food system and the concept of GE } \\
\text { - Why eating green is important }\end{array}$ & Increase awareness of GE \\
Eat local $^{(12-20)}$ & - What eating local means & Increase consumption of local foods \\
Waste less $^{(26,27,57,58)}$ & - Why eating local is important & Reduce edible food waste \\
Got protein $?^{(5,16,21-25)}$ & - Wow to reduce edible food waste & Choose environmentally conscious proteins
\end{tabular}

decisional balance (DB) and self-efficacy (SE). The survey has been validated and has strong psychometrics ${ }^{(7)}$. The GE survey was administered online at baseline and post intervention.

\section{Behaviour}

The GE behaviour scale consisted of six items $(\alpha=0 \cdot 81)^{(7)}$ assessing the frequency of pro-environmental food choices such as choosing locally grown products, shopping at farmers' markets, choosing organic or fair-trade foods and beverages, selecting meats that are raised without antibiotics or hormones, and frequency of purchasing meat or poultry labelled 'free range'. The response options were on a 5-point anchored Likert scale: 'barely ever to never' (=1); 'rarely 25\%' (=2); 'sometimes 50\%' (=3); 'often $75 \%$ ' (=4); and 'almost always' (=5). In the current sample, $\alpha=0.82$ at baseline and $\alpha=0.86$ at post, similar to the previously published coefficient alphas $^{(7)}$, indicating reliability and structural validity of this measure in the current sample.

\section{Decisional balance}

The DB scale consisted of ten items split between two factors assessing the Pros $(\alpha=0 \cdot 81)$, defined as advantages of or positive attitude towards GE, and Cons $(\alpha=0.72)$, defined as barriers of or negative attitudes towards $\mathrm{GE}^{(7)}$. The response options were on a 5-point anchored Likert scale ranging from 'not at all important' $(=1)$ to 'extremely important' $(=5)$. In this sample, for DB Pros $\alpha=0.77$ at baseline and $\alpha=0.81$ at post; for DB Cons $\alpha=0.66$ at baseline and $\alpha=0.71$ at post, indicating reliability of this measure in the current sample.

\section{Self-efficacy}

The SE scale consisted of eight items assessing situational SE to engage in GE behaviours at school and home resulting in two factors (SE School: five items, $\alpha=0.85$; SE Home: three items, $\alpha=0 \cdot 83)^{(7)}$. The response options were on a 5-point anchored Likert scale ranging from 'not at all confident' $(=1)$ to 'extremely confident' $(=5)$. For SE School in this sample, $\alpha=0.82$ at baseline and $\alpha=0.83$ at post. For SE Home, $\alpha=0.85$ at baseline and $\alpha=0.86$ at post, indicating reliability of this measure.

\section{Stage of change}

SOC reflects motivational readiness to change a behaviour $^{(42)}$. SOC in the GE survey was measured using a single item. Participants were provided with the definition of GE: eating locally grown foods, limited amounts of processed/fast foods, eating meatless meals at least one day per week, choosing organic foods as much as possible, and only taking what you plan on eating. Participants were then asked if they practise GE, according to the definition, by choosing one statement representing their perceived stage: $1=$ 'no, and I do not intend to in the next 6 months' (precontemplation); $2=$ 'no, but I intend to in the next 6 months' (contemplation); $3=$ 'no, but I intend to in the next 30 days' (preparation); $4=$ 'yes, I have been, but for less than 6 months' (action); or $5=$ 'yes, I have been for the past 6 months' (maintenance).

\section{Module assessment quizzes (knowledge)}

Module assessment quizzes were used to determine participant knowledge of GE. The quizzes reflected content that was covered in the corresponding module. Questions consisted of multiple choice or true/false answers.

\section{Module variables}

The introductory quiz questions were designed for selfassessment to provide feedback as a way to engage the participant. Feedback was based on three levels (low, middle or high) and was worded to encourage the participant to learn about the topic for the first time (low), learn more about the topic (middle) or potentially learn something new to teach others (high). At the end of each module, participants were asked to choose one statement representing their perceived stage to measure their motivational readiness to change the target behaviour (i.e. if they considered themselves a green eater, a local eater, if they make a conscious effort to reduce food waste or choose more environmentally friendly proteins) using the same stage categories as GE SOC. Participants were then asked to choose from a list of behavioural goals as a commitment to increasing awareness of the topic or making behaviour changes; confidence in achieving that goal was assessed using a scale similar to that used for SE. 


\section{Module evaluation}

Participants were asked to evaluate the GE Project using a modified (fifteen-item) version of the Instructional Material Motivation Survey (IMMS) ${ }^{(43)}$. The IMMS measures attention, relevance, confidence and satisfaction of a learning programme. The response options were on a 5-point Likert scale of 'not true', 'slightly true', 'moderately true', 'mostly true' and 'very true'. In addition, using items developed for previous process evaluations ${ }^{(44)}$, participants were also asked: (i) to rate the degree to which the GE Project motivated them to change, with response options on a 5-point Likert scale of 'not at all', 'slightly', 'moderately', 'mostly' and 'very much'; (ii) their overall opinion of the GE Project, with response options on a 5-point Likert scale of 'not good at all', 'needs improvement', 'satisfactory', 'good' and 'excellent'; and (iii) how likely they would recommend the GE Project to a friend based on a 5-point Likert scale of 'not at all', 'slightly', 'moderately', 'mostly' and 'very much'. Open-ended questions included what the participants found useful and how to improve the GE Project.

\section{Data analyses}

Data were analysed using the statistical software package IBM SPSS Statistics version 22.0 for Mac. Descriptive statistics were performed and skewness and kurtosis were analysed to determine normality of the data. All data were normally distributed. A $\chi^{2}$ analysis was performed for categorical variables. A repeated-measures ANOVA was used to determine differences in GE behaviour scores between intervention and control groups. A repeatedmeasures multiple ANOVA was used to determine differences in the Transtheoretical Model constructs, DB (Pros and Cons) and SE (School and Home), between intervention and control groups. An exploratory repeatedmeasures ANOVA was used to determine differences in knowledge score between intervention and control groups. Descriptive statistics were also performed for module evaluations. Estimating effect size for $\eta^{2}$ as well as $\phi^{2}$ was based on Cohen's determination for small (0.01), medium (0.06) and large effect size $(0 \cdot 12)^{(45)}$.

\section{Results}

\section{Participants}

A total of 1248 students were recruited to participate in the study and assigned to either intervention ( $n$ 673) or control ( $n$ 575); seventy-one students were excluded from the study sample due to non-consent or not in age range (see Fig. 1). Differences between group sizes were due to differences in the roster size of courses that were randomized. A total of 608 participants completed the baseline assessment (see Fig. 1). Participants reported a mean age of 18.9 (SD 1.1) years, a mean BMI of 23.9 (SD 3.9$) \mathrm{kg} / \mathrm{m}^{2}$, and a mean consumption of 3.3 (SD 1.5) cups of fruits and vegetables daily (see Table 2). Participants were primarily female and white. Nearly two-thirds $(64.2 \%)$ consumed red meat one to three times weekly and $71.6 \%$ were moderately or extremely interested in learning about GE. For SOC, almost two-thirds (62.8\%) were not ready to change (precontemplation and contemplation stages). There were higher proportions of females and non-freshmen in the control group compared with the experimental group but no difference for age, BMI or daily consumption of fruit and vegetables (see Table 2). There was a $19.2 \%$ attrition rate of those who completed baseline assessment to post with no difference in attrition between experimental and control groups $\left(\chi_{(1,608)}^{2}=2 \cdot 25, P=0 \cdot 13\right)$. There was no difference in any variables comparing completers with non-completers (data not shown).

\section{Green eating constructs}

There was no difference between groups for behaviours or other GE constructs at baseline. The experimental

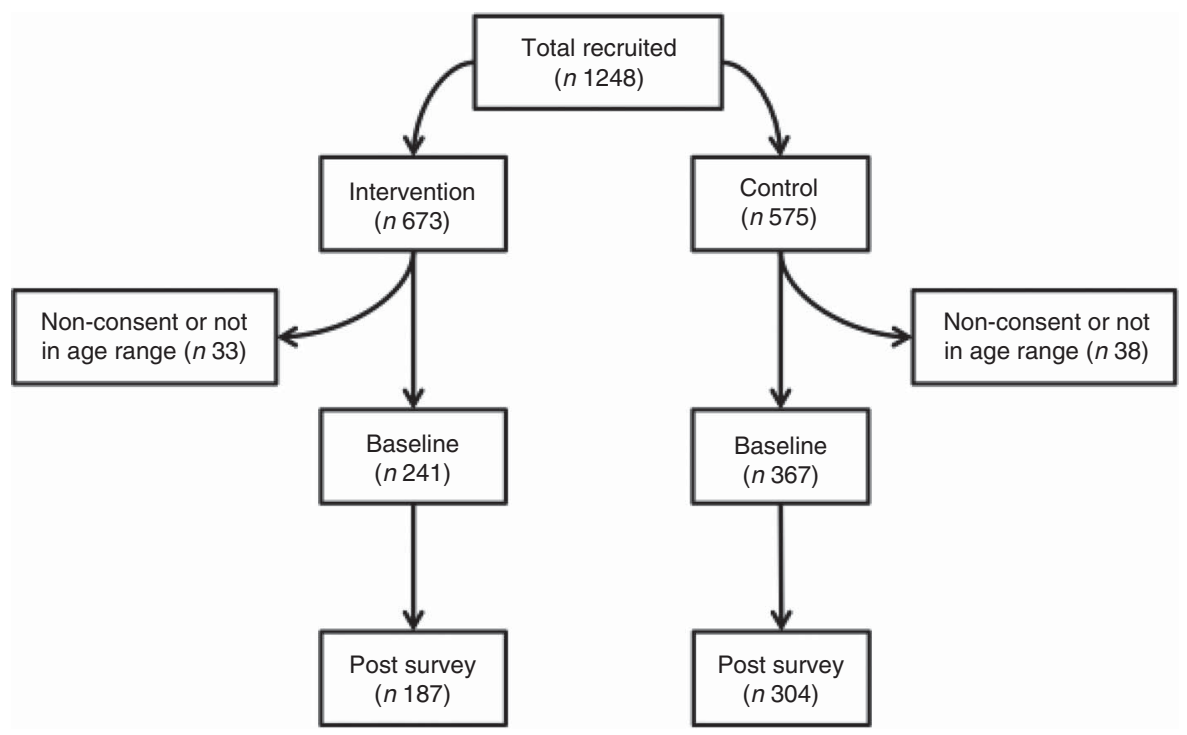

Fig. 1 Participant distribution and completion 
Table 2 Comparison of demographics between groups in the Green Eating (GE) Project, a web-based intervention to promote environmentally conscious eating behaviours in US university students aged 18-24 years

\begin{tabular}{|c|c|c|c|c|c|c|c|}
\hline & \multicolumn{2}{|c|}{ Experimental ( $n$ 241) } & \multicolumn{2}{|c|}{ Control ( $n$ 367) } & \multicolumn{2}{|c|}{ Total $(n 607)$} & \multirow[b]{2}{*}{$F$} \\
\hline & Mean & SD & Mean & SD & Mean & SD & \\
\hline Age (years) & $18 \cdot 81$ & 0.97 & 18.92 & $1 \cdot 11$ & 18.88 & 1.06 & 0.12 \\
\hline BMl $\left(\mathrm{kg} / \mathrm{m}^{2}\right)$ & 23.80 & 3.60 & 23.95 & $4 \cdot 14$ & 23.88 & 3.94 & 0.81 \\
\hline \multirow[t]{2}{*}{ Fruit and vegetables (cups/d) } & $3 \cdot 24$ & 1.48 & 3.35 & 1.48 & 3.31 & 1.48 & 0.00 \\
\hline & $n$ & $\%$ & $n$ & $\%$ & $n$ & $\%$ & $\chi^{2}$ \\
\hline \multicolumn{8}{|l|}{ Gender } \\
\hline Male & 66 & $27 \cdot 4$ & 69 & $18 \cdot 9$ & 135 & $22 \cdot 2$ & $5 \cdot 64^{*}$ \\
\hline Female & 175 & $72 \cdot 6$ & 297 & $81 \cdot 1$ & 472 & $77 \cdot 8$ & \\
\hline \multicolumn{8}{|l|}{ Race } \\
\hline White & 202 & 83.8 & 310 & $84 \cdot 7$ & 512 & $84 \cdot 3$ & 0.03 \\
\hline Non-white & 39 & $16 \cdot 2$ & 56 & $15 \cdot 3$ & 95 & $15 \cdot 7$ & \\
\hline \multicolumn{8}{|l|}{ Year } \\
\hline Freshman & 110 & $45 \cdot 6$ & 137 & 37.4 & 247 & $40 \cdot 7$ & $4 \cdot 10^{\star}$ \\
\hline Non-freshman & 131 & 54.4 & 229 & $62 \cdot 6$ & 360 & $59 \cdot 3$ & \\
\hline \multicolumn{8}{|l|}{ Red meat consumption } \\
\hline Never & 47 & $19 \cdot 7$ & 76 & $20 \cdot 9$ & 123 & 20.4 & $6 \cdot 9$ \\
\hline 1-3 times/week & 143 & $59 \cdot 8$ & 244 & $67 \cdot 0$ & 387 & $64 \cdot 2$ & \\
\hline 4-6 times/week & 42 & $17 \cdot 6$ & 39 & $10 \cdot 7$ & 81 & 13.4 & \\
\hline$\geq 7$ times/week & 7 & $2 \cdot 9$ & 5 & 1.4 & 12 & $2 \cdot 0$ & \\
\hline \multicolumn{8}{|l|}{ Interest in GE } \\
\hline Not at all & 8 & 3.3 & 11 & 3.0 & 19 & $3 \cdot 1$ & 1.87 \\
\hline Somewhat & 41 & $17 \cdot 1$ & 62 & $16 \cdot 9$ & 103 & $17 \cdot 0$ & \\
\hline Don't care either way & 20 & 8.3 & 30 & 8.2 & 50 & 8.3 & \\
\hline Moderately & 118 & $49 \cdot 2$ & 165 & $45 \cdot 1$ & 283 & $46 \cdot 7$ & \\
\hline Extremely & 53 & $22 \cdot 1$ & 98 & $26 \cdot 8$ & 151 & 24.9 & \\
\hline \multicolumn{8}{|l|}{ Stage of change for GE } \\
\hline Precontemplation & 65 & $27 \cdot 9$ & 101 & $28 \cdot 0$ & 166 & $27 \cdot 9$ & 5.43 \\
\hline Contemplation & 84 & $35 \cdot 7$ & 124 & $34 \cdot 3$ & 208 & 34.9 & \\
\hline Preparation & 34 & 14.5 & 39 & $10 \cdot 8$ & 73 & $12 \cdot 2$ & \\
\hline Action & 18 & $7 \cdot 7$ & 47 & 13.0 & 65 & $10 \cdot 9$ & \\
\hline Maintenance & 34 & 14.5 & 50 & 13.9 & 86 & $14 \cdot 1$ & \\
\hline
\end{tabular}

${ }^{\star} P<0.05,{ }^{* \star} P<0.01,{ }^{* \star *} P<0.001$.

group improved GE behaviour score from pre to post more than the control group with a small to medium effect size (see Table 3). There was a significant multivariate time $\times$ group effect for other GE constructs: DB (Pros and Cons) and SE (School and Home). For DB Pros and SE School, univariate analyses showed that the experimental group increased scores more than the control group over time with a small to medium effect size but there were no differences in DB Cons and SE Home (see Table 4). Within-group analyses showed the experimental group significantly increased GE behaviours, DB Pros and SE School with no change in the control group; however, DB Cons increased in the control group with no change in the experimental group.

\section{Green eating stage of change}

There was no difference in GE SOC at baseline between groups $\left(\chi_{(\text {ddf })}^{2}=5.43, P=0.25, \phi^{2}=0.01\right)$. There was a significant difference in stage distribution between groups at post with a small to medium effect size $\left(\chi_{(4 \mathrm{df})}^{2}=26 \cdot 81\right.$, $\left.P<0.001, \quad \phi^{2}=0.05\right)$. The experimental group was less likely to be in precontemplation and more likely to be in later stages compared with the control group (see Fig. 2).

\section{Knowledge}

There was no difference in knowledge scores between groups at baseline. There was a significant difference between groups at post for Total GE Knowledge with a medium to large effect size. Within-group analysis showed that the experimental group significantly increased knowledge score and the control group had no change (see Table 5).

\section{Module variables}

Of the 201 experimental participants who accessed the modules, $78.1 \%$ accessed all four modules, $10 \cdot 2 \%$ accessed three modules, $7.0 \%$ accessed two modules and $4.7 \%$ accessed one module. The majority of participants scored in the median range on intro quizzes, indicating moderate engagement in target behaviours. For the GE intro and local SOC algorithms, two-thirds of participants were not ready to change (i.e. in precontemplation or contemplation SOC). In contrast, $46 \%$ had taken meaningful action to change (i.e. in action or maintenance SOC) for reducing waste. Participants were likely to be in contemplation or preparation SOC (65.8\%) for using environmentally conscious proteins, indicating awareness of the problem. Most common goals selected by participants included 
Table 3 Univariate analysis for Green Eating (GE) behaviours in the GE Project, a web-based intervention to promote environmentally conscious eating behaviours in US university students aged 18-24 years

\begin{tabular}{|c|c|c|c|c|c|c|c|}
\hline & \multicolumn{2}{|c|}{ Baseline } & \multicolumn{2}{|c|}{ Post } & \multirow{2}{*}{$\frac{\text { Within }}{t}$} & \multirow{2}{*}{$\frac{\text { Between }}{F}$} & \multirow[b]{2}{*}{$\eta^{2}$} \\
\hline & Mean & SD & Mean & SD & & & \\
\hline \multicolumn{8}{|c|}{ Behaviours $F(1,405 \mathrm{df})=13.89, P<0.001, \eta^{2}=0.03$} \\
\hline $\begin{array}{l}\text { Experimental }(n \text { 157) } \\
\text { Control }(n 250)\end{array}$ & $\begin{array}{l}2.33 \\
2.45\end{array}$ & $\begin{array}{l}0.80 \\
0.81\end{array}$ & $\begin{array}{l}2 \cdot 60 \\
2.47\end{array}$ & $\begin{array}{l}0.81 \\
0.85\end{array}$ & $\begin{array}{l}-4.97^{\star \star \star} \\
-0.59\end{array}$ & $13 \cdot 89^{\star \star *}$ & 0.03 \\
\hline
\end{tabular}

Behaviour score consisted of six behaviours based on an anchored Likert scale from 1 ( = 'barely ever to never') to 5 (= 'almost always'). The higher the score, the more frequent the behaviours.

${ }^{\star} P<0.05,{ }^{\star \star} P<0.01,{ }^{\star \star *} P<0.001$.

Table 4 Univariate analyses for the Green Eating (GE) constructs DB Pros, DB Cons, SE School and SE Home in the GE Project, a webbased intervention to promote environmentally conscious eating behaviours in US university students aged 18-24 years

\begin{tabular}{|c|c|c|c|c|c|c|c|}
\hline & \multicolumn{2}{|c|}{ Baseline } & \multicolumn{2}{|c|}{ Post } & \multirow{2}{*}{$\frac{\text { Within }}{t}$} & \multirow{2}{*}{$\frac{\text { Between }}{F}$} & \multirow[b]{2}{*}{$\eta^{2}$} \\
\hline & Mean & SD & Mean & SD & & & \\
\hline \multicolumn{8}{|l|}{ DB Pros } \\
\hline Experimental ( $n$ 179) & 3.75 & 0.66 & 3.85 & $0 \cdot 61$ & $-2 \cdot 16^{*}$ & $5 \cdot 06^{*}$ & 0.01 \\
\hline Control $(n$ 290) & $3 \cdot 71$ & 0.68 & $3 \cdot 68$ & 0.74 & 0.91 & & \\
\hline \multicolumn{8}{|l|}{ DB Cons } \\
\hline Experimental ( $n$ 162) & $2 \cdot 97$ & 0.69 & 3.05 & 0.75 & $-1 \cdot 31$ & 1.62 & 0.004 \\
\hline Control (n 267) & 2.98 & 0.67 & $3 \cdot 14$ & 0.71 & $-4 \cdot 12^{\star \star \star}$ & & \\
\hline \multicolumn{8}{|l|}{ SE School } \\
\hline Experimental $(n$ 178) & 2.46 & 0.72 & $2 \cdot 68$ & 0.73 & $-4 \cdot 28^{\star \star \star}$ & $15 \cdot 62^{\star \star \star}$ & 0.03 \\
\hline Control (n 292) & $2 \cdot 37$ & 0.76 & $2 \cdot 35$ & 0.74 & 0.63 & & \\
\hline \multicolumn{8}{|l|}{ SE Home } \\
\hline Experimental ( $n$ 184) & $3 \cdot 38$ & 0.86 & 3.48 & 0.83 & -1.82 & $2 \cdot 92$ & 0.006 \\
\hline Control (n 299) & 3.39 & 0.91 & $3 \cdot 38$ & 0.94 & 0.29 & & \\
\hline
\end{tabular}

Multivariate analyses: Wilks' $\lambda=0.96, F(3,410 \mathrm{df})=5.12, P<0.01, \eta^{2}=0.04$

The decisional balance constructs, DB Pros and DB Cons, consisted of positive aspects and barriers associated with GE, respectively, based on an anchored Likert scale ranging from 1 (= 'not at all important') to 5 (= 'extremely important'). The higher the score for DB Pros the more positively associated GE and the higher the score for DB Cons the more barriers associated with GE. The self-efficacy constructs, SE School and SE Home, consisted of eight items assessing the confidence of the subject to maintain GE behaviours while in a school or home environment, respectively, based on an anchored Likert scale ranging from 1 ( = 'not at all confident') to 5 (='extremely confident'). The higher the score, the higher the confidence in that environment.

${ }^{\star} P<0.05,{ }^{* \star} P<0.01,{ }^{* *} P<0.001$

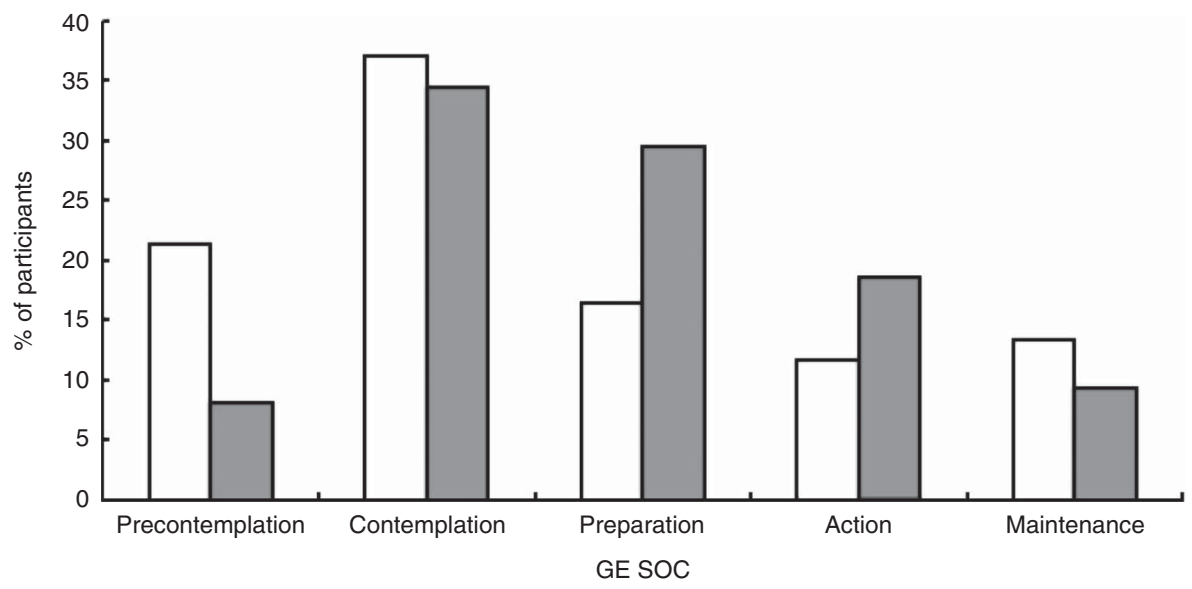

Fig. 2 Stage of change (SOC) for Green Eating (GE) ( $\square$, control group; $\square$, experimental group) at the post assessment in the GE Project, a web-based intervention to promote environmentally conscious eating behaviours in US university students aged 18-24 years

'make one healthy change to your diet', 'try one locally produced food on or off campus', 'take less food at one meal every day' and 'eat veggies instead of ham or bacon at breakfast' (see Table 6).

\section{Module evaluation}

Participants evaluated the modules as slightly above neutral in holding their attention, being relevant in their lives and giving them a sense of satisfaction, and were 
Table 5 Univariate analysis for Total Green Eating (GE) Knowledge in the GE Project, a web-based intervention to promote environmentally conscious eating behaviours in US university students aged 18-24 years

\begin{tabular}{|c|c|c|c|c|c|c|c|}
\hline & \multicolumn{2}{|c|}{ Baseline } & \multicolumn{2}{|c|}{ Post } & \multirow{2}{*}{$\frac{\text { Within }}{t}$} & \multirow{2}{*}{$\frac{\text { Between }}{F}$} & \multirow[b]{2}{*}{$\eta^{2}$} \\
\hline & Mean & SD & Mean & SD & & & \\
\hline \multicolumn{8}{|c|}{ Total GE Knowledge $F(1,407 \mathrm{df})=51.15, P<0.001, \eta^{2}=0.11$} \\
\hline Experimental ( $n$ 105) & 8.02 & $2 \cdot 24$ & $10 \cdot 16$ & 2.52 & $-8 \cdot 17^{\star \star \star}$ & $51 \cdot 15^{\star \star \star}$ & 0.11 \\
\hline Control $(n 304)$ & 7.82 & $2 \cdot 22$ & 7.91 & 2.47 & -0.673 & & \\
\hline
\end{tabular}

Knowledge score based on fifteen questions associated with module content (each correct item $=1$, point range 0 to 15 ). The higher the score the greater understanding of module content.

${ }^{\star} P<0.05,{ }^{\star \star} P<0.01,{ }^{\star * \star} P<0.001$

confident that they understood and could complete the modules based on IMMS scores. A majority of the participants rated the project as moderately to mostly motivational (69.1\%), had a good or excellent overall opinion (77.1\%) and would likely recommend it to a friend (65.9\%; see Table 7). For the open-ended questions, students found the videos, language and layout of the project useful. To improve the project, they recommended adding more applicable scenarios for students eating in the dining halls and to add more videos.

\section{Discussion}

To the knowledge of the researchers, the GE Project was the first to investigate whether an online, interactive intervention would be successful in motivating university students to adopt GE behaviours. As hypothesized, the GE Project effectively increased GE behaviours in university students. In addition, the intervention increased DB Pros and SE School. There was also an increase in knowledge. The GE Project was also the first to explore SOC constructs for each individual target behaviour (i.e. local eating, reducing waste and choosing more environmentally friendly proteins). The GE Project demonstrated that, in the short term, students improved attitudes and behaviours related to environmentally conscious eating. If replicated, it could serve as a model for other universities and interventions could be developed for other populations to promote GE behaviours and, ultimately, motivate consumers to play a role in mitigating the environmental impact of the food system.

The results indicating that the experimental group significantly increased GE behaviours, DB Pros and SE School compared with control are similar to other studies utilizing online interventions in this age population. After completion of two 45-min sessions of an online programme to improve nutrition and fitness behaviours in university students, Franko et $a l .{ }^{(38)}$ found the experimental group increased fruit and vegetable consumption and were more likely to advance a stage in readiness to eat more fruits and vegetables and decrease fat consumption compared with control. Greene et al. ${ }^{(39)}$ conducted a 10-week online intervention to promote healthful eating and physical activity in university students. The intervention was effective in increasing and maintaining fruit and vegetable consumption and physical activity levels in the intervention group at post and 15-month follow-up. Milan and White ${ }^{(40)}$ compared the effects of an online stage-tailored $v$. a nontailored traditional intervention to increase folic acid supplementation use in university females. The tailored intervention was effective in significantly increasing selfefficacy and the pros of the behaviour. Poddar et al. ${ }^{(41)}$ conducted a 5-week nutrition education intervention to increase dairy intake in university students and found the intervention was successful in significantly increasing selfefficacy for the behaviour. The present study was not effective in increasing GE Home but this outcome was expected as the impact of the modules was intentionally designed for the university setting and not the home setting.

In addition to advantages of GE, DB Pros can also be defined as positive attitudes towards GE. Previous research has shown that positive attitudes towards similar aspects as those found within the GE definition are associated with increased dietary quality in university students ${ }^{(35,36)}$. Although the present study did not assess dietary quality in university students, previous research has found that aspects of dietary quality increased with advancing GE $\mathrm{SOC}^{(46)}$. Further research is needed to determine if adopting GE behaviours increases dietary quality in university students and the association between dietary quality and overall environmental impact.

The GE Project was not effective in reducing DB Cons. This is most likely due to the content of the project promoting the advantages of GE (DB Pros) and not addressing the barriers of GE (DB Cons). Research has shown that advancement through stages is associated with a reduction of cons for many health behaviours ${ }^{(47)}$. Including more information on overcoming barriers of GE within the project could motivate students to adopt GE behaviours and advance them through the stages but this would require further investigation.

At baseline, the majority of participants (62.8\%) were not ready to adopt GE behaviours. This is similar to previous research conducted in the laboratory ${ }^{(7)}$. For the present study, at post intervention, participants in the experimental group were less likely to be in precontemplation and more likely to be in later stages compared with control. This is similar to the study conducted by Milan and White ${ }^{(40)}$ 
Table 6 Module variables (intro quiz category, stage of change (SOC), goal and confidence) in the Green Eating (GE) Project, a web-based intervention to promote environmentally conscious eating behaviours in US university students aged 18-24 years

\begin{tabular}{|c|c|c|c|c|c|c|c|c|c|c|c|}
\hline \multirow[b]{2}{*}{ Module } & \multicolumn{3}{|c|}{ Intro quiz } & \multicolumn{3}{|c|}{ SOC } & \multicolumn{3}{|l|}{ Goal } & \multicolumn{2}{|c|}{ Confidence } \\
\hline & & $n$ & $\%$ & & $n$ & $\%$ & & $n$ & $\%$ & Mean & SD \\
\hline \multirow[t]{4}{*}{ GE intro } & & & & Precont. & 39 & $24 \cdot 1$ & Assess what you're eating & 89 & 58.9 & $3 \cdot 26$ & 0.81 \\
\hline & Low & 54 & $27 \cdot 7$ & Cont. & 67 & 41.4 & Watch the documentary, Food Fight & 31 & 20.5 & 3.19 & 0.65 \\
\hline & Mid & 130 & $66 \cdot 7$ & Prep. & 29 & $17 \cdot 9$ & Visit URI East Farm & 28 & 18.5 & 3.61 & 0.83 \\
\hline & High & 11 & $5 \cdot 6$ & $\begin{array}{l}\text { Act. } \\
\text { Main. }\end{array}$ & $\begin{array}{l}13 \\
14\end{array}$ & $\begin{array}{l}8.0 \\
8.6\end{array}$ & Join Slow Food URI - a group on campus dedicated to the sustainable food movement & 3 & $2 \cdot 0$ & 3.00 & $2 \cdot 00$ \\
\hline \multirow[t]{5}{*}{ Local } & & & & Precont. & 21 & 13.5 & Find one local food and try it & 93 & 62.4 & 3.47 & 0.77 \\
\hline & Low & 75 & $40 \cdot 3$ & Cont. & 85 & $54 \cdot 8$ & Find a local food in season and try it & 26 & $17 \cdot 4$ & 3.50 & 0.99 \\
\hline & Mid & 107 & 57.5 & Prep. & 20 & $12 \cdot 9$ & Cook a local, in-season recipe for your friends & 23 & $15 \cdot 4$ & 3.87 & 0.87 \\
\hline & High & 4 & $2 \cdot 2$ & Act. & 14 & 9.0 & Watch the documentary, Ingredients: The Local Food Movement Takes Root & 7 & 4.7 & 3.43 & 0.79 \\
\hline & & & & Main. & 15 & 9.7 & & & & & \\
\hline \multirow[t]{4}{*}{ Waste } & & & & Precont. & 13 & $8 \cdot 0$ & Take less food at one meal every day & 125 & $77 \cdot 6$ & 4.01 & 0.80 \\
\hline & Low & 33 & $20 \cdot 1$ & Cont. & 25 & $15 \cdot 4$ & Talk to a friend about food waste & 17 & $10 \cdot 6$ & 4.24 & 0.83 \\
\hline & Mid & 110 & $67 \cdot 1$ & Prep. & 49 & $30 \cdot 2$ & Keep a journal about food waste for $3 \mathrm{~d}$ & 13 & $8 \cdot 1$ & $3 \cdot 31$ & 1.00 \\
\hline & High & 21 & $12 \cdot 8$ & $\begin{array}{l}\text { Act. } \\
\text { Main. }\end{array}$ & $\begin{array}{l}37 \\
38\end{array}$ & $\begin{array}{l}22.8 \\
23.5\end{array}$ & Watch the documentary, Dive & 6 & 3.7 & 3.67 & 0.82 \\
\hline \multirow[t]{5}{*}{ Protein } & & & & Precont. & 18 & 11.0 & At breakfast, load up on veggies instead of ham or bacon & 57 & 35.4 & 3.56 & 0.80 \\
\hline & Low & 34 & $20 \cdot 2$ & Cont. & 54 & 32.9 & Replace beef with chicken, beans, chickpea, or edamame & 49 & 30.4 & 3.39 & 0.86 \\
\hline & Mid & 114 & 67.9 & Prep. & 54 & 32.9 & Watch the documentary, Meat the Truth & 28 & $17 \cdot 4$ & 3.32 & 0.86 \\
\hline & High & 20 & 11.9 & Act. & 21 & $12 \cdot 8$ & If you already eat Meatless Mondays, try Meatless Tuesdays through Sundays & 27 & $16 \cdot 8$ & 3.81 & 0.90 \\
\hline & & & & Main. & 17 & $10 \cdot 4$ & & & & & \\
\hline
\end{tabular}

Precont., precontemplation; cont., contemplation; prep., preparation; act., action; main., maintenance; URI, University of Rhode Island. 
Table 7 Programme evaluation of the Green Eating (GE) Project, a web-based intervention to promote environmentally conscious eating behaviours in US university students aged 18-24 years

\begin{tabular}{|c|c|c|}
\hline & Mean & SD \\
\hline \multicolumn{3}{|l|}{ IMMS (n 176) } \\
\hline Attitude & 3.40 & 0.85 \\
\hline Relevance & 3.47 & 0.91 \\
\hline Confidence & $4 \cdot 10$ & 0.78 \\
\hline Satisfaction & 3.30 & 0.96 \\
\hline \multirow[t]{2}{*}{ Total } & 3.62 & 0.65 \\
\hline & $n$ & $\%$ \\
\hline \multicolumn{3}{|l|}{ Motivation } \\
\hline Not at all & 4 & $2 \cdot 2$ \\
\hline Slightly & 30 & $16 \cdot 2$ \\
\hline Moderately & 85 & 45.9 \\
\hline Mostly & 43 & $23 \cdot 2$ \\
\hline Very much & 23 & $12 \cdot 4$ \\
\hline \multicolumn{3}{|l|}{ Opinion } \\
\hline Not good at all & 1 & 0.5 \\
\hline Needs improvement & 5 & $2 \cdot 7$ \\
\hline Satisfactory & 36 & $19 \cdot 7$ \\
\hline Good & 96 & $52 \cdot 5$ \\
\hline Excellent & 45 & 24.6 \\
\hline \multicolumn{3}{|l|}{ Recommend to friend } \\
\hline Not at all & 8 & 4.3 \\
\hline Slightly & 27 & $14 \cdot 6$ \\
\hline Moderately & 67 & $36 \cdot 2$ \\
\hline Mostly & 55 & $29 \cdot 7$ \\
\hline Very much & 28 & $15 \cdot 1$ \\
\hline
\end{tabular}

IMMS, Instructional Material Motivational Survey. $n$ varies.

in which the stage-tailored group was also more likely to be in a later stage compared with the non-tailored group. Although the present study was not stage-tailored, similar movement through stages was seen. To increase further movement through stages, future studies could tailor the GE modules to each participant's stage for the target behaviour.

Knowledge scores also significantly increased in the experimental group compared with control. The knowledge items were created from content in the module and have not been validated; therefore, the increase in knowledge is exploratory. Another study found that, following exposure to a nutrition-based intervention, nutrition knowledge significantly increased in experimental students compared with control $^{(38)}$. It is a limitation of the present study that the knowledge items were not validated prior to study induction. Validating knowledge items would provide a more robust instrument for determining the effectiveness of the modules in achieving the learning objectives.

The SOC constructs created for each target behaviour (local, waste and protein) provide further insight into some of the individual aspects of the GE definition. First, following the local module, over two-thirds of participants (68.3\%) were in precontemplation or contemplation indicating they were not ready to change. Little research has been conducted investigating US university students' perspectives about local food. International studies have found university students felt it was important for them to purchase foods from local farms ${ }^{(34)}$ and categorized descriptions associated with local foods as ethical ${ }^{(30)}$. In contrast, research has found that high-school students from the USA were not concerned about where their food originated $^{(48)}$ and did not find it personally important that foods be grown locally ${ }^{(49,50)}$. It is possible students in the present study found it difficult to access local foods on campus or travel to places that sell local foods. Many underclassmen at the university where the study took place do not have cars on campus. It is also possible that students are unaware when they are consuming local foods. Although dining services at the university sources foods locally whenever possible, local foods were not labelled (M McCullough, Associate Administrator of Dining Services, University of Rhode Island, personal communication, 2014).

Second, under half of students (43.9\%) were not ready to choose environmentally friendly proteins. A survey found university students cited lack of availability, lack of affordable options and lack of protein in the diet as barriers towards following a plant-based diet ${ }^{(51)}$. It is possible the current sample of university students had similar thoughts but this would need to be confirmed by future research. Other studies conducted in adult consumers found there was also little knowledge about the environmental impact of animal food production ${ }^{(52)}$ and adult consumers believed reducing meat consumption would have little impact on the environment ${ }^{(53)}$.

Third, in contrast to the local and protein modules SOC, the waste module SOC showed under half of students (46.3\%) were in action or maintenance indicating they were actively reducing their food waste. Research has shown that increasing awareness about food waste can decrease the generation of food waste. One study found that using prompt-type poster messaging in a dining hall informing students to reduce their food waste resulted in a $15 \%$ decrease of food waste generation ${ }^{(33)}$. The students in the present study were most likely in later stages due to environmental interventions currently in place to reduce food waste. The university dining halls have been trayless since $2007^{(50)}$ and research has shown that going trayless in dining halls can reduce food waste by between 25 and 32 $\%^{(54,55)}$ by forcing students to take only what they can carry.

Students rated the GE Project with a total IMMS score greater than 3.5 , which indicates a better than average rating ${ }^{(43)}$. A majority of students $(77 \cdot 1 \%)$ had a positive overall opinion of the GE Project, rating it as good to excellent. Students also would moderately to most likely recommend it to a friend $(65.9 \%)$. Students found the layout of the GE Project and videos embedded in the modules useful. To improve the GE Project, they recommended adding even more videos and more interactivity. Although the students rated the GE Project positively, increased interactivity and individual tailoring may be important for future interventions.

A few limitations of the GE Project should be mentioned. Although the intervention was effective the population was convenient and homogeneous, reducing 
the generalizability of the study to other populations. Interventions should be conducted in other universities or more diverse populations to determine effectiveness and the intervention would need to be modified for nonuniversity populations. The module topics were also limited and, while important, they are in no way comprehensive. Future research could include more or other topics pertaining to GE such as processed and organic food. Also, the study was limited in duration and did not conduct a follow-up evaluation. Therefore, maintenance of the behaviour is unknown. Longer-duration studies with follow-up analysis should be conducted to determine how GE behaviours change over time. While increasing awareness and informing consumers is an important first step, there is also a need to assess actual environmental impact of the proposed behaviour changes. Future research could include directly measuring environmental behaviours following participation in the GE Project, such as the amount of food waste reduction. To better inform the consumer about food choice, there is also a need for research to analyse the entire life cycle of a food product.

\section{Conclusions}

Informing consumers of sustainable food choices such as those found within the GE Project could potentially motivate them to adopt dietary changes and ultimately assist in mitigating the environmental impact of the food system. University students are a unique consumer population because at this stage in their life they are solidifying their beliefs. To the authors' knowledge, the GE Project was the first online, interactive programme to effectively motivate university students to adopt GE behaviours. Future studies could use the GE Project as a template to motivate students at other universities or other populations such as adult consumers.

\section{Acknowledgements}

Financial support: This work was supported by The University of Rhode Island. The University of Rhode Island had no role in the design, analysis or writing of this article. Conflict of interest: None declared. Authorship: Literature search: J.T.M. Figures: J.T.M. Study design: J.T.M., B.L.S., I.E.L. and G.W.G. Data collection: J.T.M. Data analysis: J.T.M. and G.W.G. Data interpretation: J.T.M. and G.W.G. Writing of manuscript: J.T.M., I.E.L., B.L.S. and G.W.G. All authors approved the final version of this paper. Ethics of buman subject participation: The Green Eating Project was approved by the Institutional Review Board of the University of Rhode Island.

\section{References}

1. Pimentel D \& Pimentel M (2003) World population, food, natural resources, and survival. World Futures 59, 145-167.
2. Ericksen PJ (2007) Conceptualizing food systems for global environmental change research. Glob Environ Change 18, 234-245.

3. Smith P \& Gregory PJ (2013) Climate change and sustainable food production. Proc Nutr Soc 72, 21-28.

4. US Environmental Protection Agency (2012) Agricultural nonpoint source fact sheet. http://water.epa.gov/polwaste/ nps/agriculture_facts.cfm (accessed September 2013).

5. Garnett T (2011) Where are the best opportunities for reducing greenhouse gas emissions in the food system (including the food chain)? Food Policy 36, S23-S32.

6. Hockstad L \& Weitz M (2013) Inventory of US Greenhouse Gas Emissions and Sinks: 1990-2011. Washington, DC: US Environmental Protection Agency.

7. Weller K, Greene GW, Redding CA et al. (2014) Development and validation of green eating behaviors, stage of change, decisional balance and self efficacy scales in college students. J Nutr Educ Behav 46, 324-333.

8. Nash JT, Arts J, Lofgren IE et al. (2013) Stage stability and test-retest reliability of the Green Eating Survey. J Nutr Educ Behav 45, Suppl. 4, S43-S44.

9. Edwards-Jones G, Canals LMI, Hounsome N et al. (2008) Testing the assertion that 'local food is best': the challenges of an evidence-based approach. Trends Food Sci Technol 19, 265-274.

10. Hospido A, Canals LMI, McLaren S et al. (2009) The role of seasonality in lettuce consumption: a case study of environmental and social aspects. Int J Life Cycle Assess 14, 381-391.

11. Wong A \& Hallsworth A (2012) Farm-to-form: a proposed revision of the classical food miles concept. Int $J$ Food System Dyn 3, 74-81.

12. Blanke MM \& Burdick B (2005) Food (miles) for thought: energy balance for locally-grown versus imported apple fruit. Environ Sci Pollut Res 12, 125-127.

13. Jones A (2002) An environmental assessment of food supply chains: a case study on dessert apples. Environ Manage 30, 560-576.

14. Pirog R, Van Pelt T, Enshayan K et al. (2001) Food, Fuel, and Freeways: An Iowa Perspective on How Far Food Travels, Fuel Usage, and Greenhouse Gas Emissions. Ames, IA: Leopold Center for Sustainable Agriculture.

15. Van Passel S (2013) Food miles to assess sustainability: a revision. Sustain Dev 21, 1-17.

16. Weber CL \& Matthews HS (2008) Food-miles and the relative climate impacts of food choices in the United States. Environ Sci Technol 42, 3508-3513.

17. Saunders C \& Hayes P (2007) Air Frieght Transport of Fresh Fruit and Vegetables. Agribusiness and Economist Research Unit. Christchurch: Lincoln University.

18. Darby K, Batte MT, Ernst S et al. (2008) Decomposing local: a conjoint analysis of locally produced foods. Am J Agric Econ 90, 476-486.

19. Martinez S, Hand M, Da Pra M et al. (2010) Local Food Systems: Concepts, Impacts, and Issues. Economic Research Report no. ERR-97. Washington, DC: US Department of Agriculture, Economic Research Service.

20. Otto D \& Varner T (2005) Consumers, Vendors, and the Economic Importance of Iowa Farmers' Markets: An Economic Impact Survey Analysis. Ames, IA: Leopold Center for Sustainable Agriculture.

21. Baroni L, Cenci L, Tettamanti M et al. (2007) Evaluating the environmental impact of various dietary patterns combined with different food production systems. Eur J Clin Nutr 61, 279-286.

22. Carlsson-Kanyama A \& Gonzalez AD (2009) Potential contributions of food consumption patterns to climate change. Am J Clin Nutr 89, issue 5, 1704S-1709S.

23. Pimentel D \& Pimentel M (2003) Sustainability of meatbased and plant-based diets and the environment. Am J Clin Nutr 78, 3 Suppl., 660S-663S. 
24. Walker P, Rhubart-Berg P, McKenzie S et al. (2005) Public health implications of meat production and consumption. Public Health Nutr 8, 348-356.

25. Horrigan L, Lawrence RS \& Walker P (2002) How sustainable agriculture can address the environmental and human health harms of industrial agriculture. Environ Health Perspect 110, 445-456.

26. Hall KD, Guo J, Dore M et al. (2009) The progressive increase of food waste in America and its environmental impact. PLoS One 4, e7940.

27. Gunders D (2012) Wasted: How America Is Losing Up to 40 Percent of Its Food from Farm to Fork to Landfill. New York: National Resources Defense Council.

28. US Department of Agriculture \& US Environmental Protection Agency (2001) Waste Not, Want Not: Feeding the Hungry and Reducing Solid Waste Through Food Recovery. Washington, DC: EPA.

29. Vermeir I \& Verbeke W (2008) Sustainable food consumption among young adults in Belgium: theory of planned behaviour and the role of confidence and values. Ecol Econ $\mathbf{6 4}$, 542-553.

30. Makiniemi JP, Pirttila-Backman AM \& Pieri M (2011) Ethical and unethical food. Social representations among Finnish, Danish and Italian students. Appetite 56, 495-502.

31. Wilkins JL, Bowdish E \& Sobal J (2000) University student perceptions of seasonal and local foods. J Nutr Educ 32, 261-268.

32. Dahm MJ, Samonte AV \& Shows AR (2009) Organic foods: do eco-friendly attitudes predict eco-friendly behaviors? J Am Coll Health 58, 195-202.

33. Whitehair KJ, Shanklin CW \& Brannon LA (2013) Written messages improve edible food waste behaviors in a university dining facility. J Acad Nutr Diet 113, 63-69.

34. Bagdonis JM \& Bruening TH (2009) Russian agricultural students' perceptions of local foods and sustainable agriculture: implications for training the next generation of russian agricultural leaders. In Proceedings of the $24 \mathrm{th}$ Annual Meeting, EARTH University, Costa Rica, pp. 62-70. Raleigh, NC: North Carolina State University and Association for International Agricultural and Extension Education.

35. Pelletier JE, Laska MN, Neumark-Sztainer D et al. (2013) Positive attitudes toward organic, local, and sustainable foods are associated with higher dietary quality among young adults. $J$ Acad Nutr Diet 113, 127-132.

36. Gerson A, Goto K, Wolff C et al. (2013) Food, health and values: the effects of attitudes and behaviors regarding sustainable food practices on overall diet quality among college students. Calif J Health Promot 11, 53-60.

37. Hekler EB, Gardner CD \& Robinson TN (2010) Effects of a college course about food and society on students' eating behaviors. Am J Prev Med 38, 543-547.

38. Franko DL, Cousineau TM, Trant M et al. (2008) Motivation, self-efficacy, physical activity and nutrition in college students: randomized controlled trial of an internet-based education program. Prev Med 47, 369-377.

39. Greene GW, White AA, Hoerr SL et al. (2012) Impact of an online healthful eating and physical activity program for college students. Am J Health Promot 27, e47-e58.

40. Milan JE \& White AA (2010) Impact of a stage-tailored, web-based intervention on folic acid-containing multivitamin use by college women. Am J Health Promot 24, 388-395.
41. Poddar KH, Hosig KW, Anderson ES et al. (2010) Webbased nutrition education intervention improves self-efficacy and self-regulation related to increased dairy intake in college students. J Am Diet Assoc 110, $1723-1727$.

42. Prochaska JO \& DiClemente CC (1992) Stages of change in the modification of problem behaviors. Prog Behav Modif 28, 183-218.

43. Keller JM (2009) Motivational Design for Learning and Performance: The ARCS Model Approach, 1st ed. New York: Springer.

44. Dour CA, Horacek TM, Schembre SM et al. (2013) Process evaluation of Project WebHealth: a nondieting web-based intervention for obesity prevention in college students. J Nutr Educ Behav 45, 288-295.

45. Cohen J (1992) A power primer. Psychol Bull 112, 155-159.

46. Brown G (2013) Green eating and dietary quality of university students. Master's Thesis, University of Rhode Island; available at http://digitalcommons.uri.edu/cgi/ viewcontent .cgi?article $=1023 \&$ context $=$ theses

47. Prochaska JO, Velicer WF, Rossi JS et al. (1994) Stages of change and decisional balance for 12 problem behaviors. Health Psychol 13, 39-46.

48. Harmon AH \& Maretzki AN (2006) A survey of food system knowledge, attitudes, and experiences among high school students. J Hunger Environ Nutr 1, 59-82.

49. Bissonnette MM \& Contento IR (2001) Adolescents' perspectives and food choice behaviors in terms of the environmental impacts of food production practices: application of a psychosocial model. J Nutr Educ 33, 72-82.

50. Robinson-O'Brien R, Larson N, Neumark-Sztainer D et al. (2009) Characteristics and dietary patterns of adolescents who value eating locally grown, organic, nongenetically engineered, and nonprocessed food. J Consum Behav $\mathbf{4 1}$, $11-18$.

51. Wyker BA \& Davison KK (2010) Behavioral change theories can inform the prediction of young adults' adoption of a plant-based diet. J Nutr Educ Behav 42, 168-177.

52. Lea E \& Worsley A (2008) Australian consumers' foodrelated environmental beliefs and behaviours. Appetite 50, 207-214

53. Tobler C, Visschers VH \& Siegrist M (2011) Eating green. Consumers' willingness to adopt ecological food consumption behaviors. Appetite 57, 674-682.

54. Kim K \& Morawski S (2012) Quantifying the impact of going trayless in a university dining hall. J Hunger Environ Nutr $\mathbf{7}$, 482-486.

55. Sarjahani A, Serrano EL \& Johnson R (2009) Food and non-edible, compostable waste in a university dining facility. J Hunger Environ Nutr 4, 95-102.

56. Godfray HC, Beddington JR, Crute IR et al. (2010) Food security: the challenge of feeding 9 billion people. Science 327, 812-818.

57. Postel SL, Daily GC \& Ehrlich PR (1996) Human appropriation of renewable fresh water. Science 271, 785-788.

58. Quested T \& Parry A (2011) Estimates for household food and drink waste in the UK 2011. http://www.wrap.org.uk/ content/new-estimates-household-food-and-drink-waste-uk (accessed August 2013). 